\title{
THE PRESIDENTJAL SPECIAL INITIATIVE ON CASSAVA: A BANE OR BLESSING TO GHANA'S SMALLHOLDER FARMERS
}

\author{
Steve Tonah,
}

Department of Sociology, University of Ghana, Legon, Ghana. Email:

\section{ABSTRACT}

This paper analyses the Presidential Special Initiative on Cassava, a Gtanaian govermment initiative that seeks to increase substantially the nation's foreign exchange eamings through the transformation of smallholder production methods and the processing of cassava for export. Research work was carried out in the Gomoa and the Awutu-Effutu-Senya Districts in Ghana's Central Region. Eighty (80) farmers, as well as members of the farmers' association and the staff and management of the Ayensu Starch Company were interviewed. The findamental method used was participant observation. This was complemented with interviews, questionnaires and focus group discussions. The paper asserts that several bottlenecks are impeding attempts to increase smallholder cassava production. The morale of farmers is low and the starch factory is currently working well below its installed capacity. The paper questions the rationale behind successive governments' policy of radically transforming smallholder subsistence production and suggests the need for a gradual process through the formation of active out-grower cooperatives as well as the provision of extension support, credit and training to farmers.

KEY WORDS: Subsistence and Commercial Farming, cassava Production, Government Agricultural Policy, Agricultural Exports

\section{INTRODUCTION}

Cassava (Manihot esculenta), otherwise called manioc, is a perennial woody shrub with an edible root that is widely grown throughout Sub-Saharan Africa by smallholder subsistence farmers. Cassava is a major food-crop in many parts of the continent and forms the main diet among rural and urban residents in several countries. Because of its peculiar characteristics, smallholder farmers generally regard cassava as a "saviour crop". It is easy to grow and can grow on poor soils and marginal lands where other crops cannot. Unlike other staple food-crops (such as maize) cassava requires little or no fertilizer and pesticides. It is comparatively drought-resistant and suitable for Africa's largely rain-fed agriculture under conditions of extreme climatic variability. Cassava is eaten raw or simply boiled and consumed on the farm. It is also processed into a variety of granules, pastes, and flours. The stem is cut and reserved for future use while the leaves are consumed as a green vegetable in soups and stews throughout the continent. Besides, cassava has numerous advantages for smallholder subsistence farmers. Because it can be harvested anytime from eight to 24 months after planting, it can be left in the ground as a safeguard against unexpected 
food shortages or until market, processing or other conditions are favorable. These factors explain why smallholder rural farmers in Africa regard cassava as a key crop for their sustenance and livelihood (FAO, 2004; IITA, 2004; Volz, 1990). '

In spite of cassava's numerous advantages for the smallholder farmer, most African governments (including Ghana) did not promote the cultivation of cassava and other root and tuber crops such as cocoyam, yam, plantain etc. Most of the research was devoted to the cultivation of cereals such as rice, maize and wheat. Cassava was considered as an "inferior food", reserved for the poor whose consumption of the crop was destined to decline as incomes increased. It was argued that Africa's elite and the growing urban population were rapidly showing preference for "modern and sophisticated" cereals such as wheat and rice.

In Ghana, the shift in government agricultural policy from an emphasis on large-scale cultivation of grains to the promotion of cassava was engendered by the drought of the early 1980s that resulted in the failure of most food crops except cassava. The government has since then recognized the potential significance of cassava to increasing national food security, reducing under-nourishment and increasing income among rural subsistence farmers (Nweke, 2004).

This paper examines the impact of the Presidential Special Initiative (PSI) on cassava, a Ghanaian government initiative introduced in 2001 that seeks to increase substantially the nation's foreign exchange earnings through increased production and processing of cassava for export. The government's agricultural policy also aims at improving the income of rural smallholder farmers and their general livelihood by transforming the production of cassava from its small-scale, low-yielding, and subsistence character into a high-yielding, market-oriented cash crop. This analysis is made against the background of failed attempts by successive Ghanaian governments to transform the nature of smallholder farming in the country and the fascination of policy makers with large-scale commercial agriculture. The paper begins with a presentation of the study area and methodology and then dilates on cassava production in the study area. It then examines theoretical issues relating to the transformation of subsistence farmers into commercial farmers. The paper analyses the PSI on cassava project. Finally, there is a critical discussion of the government's attempt at transforming cassava into a commercial product and the prospects for Ghana's smallholder farmers.

\section{STUDY AREA AND METHODOLOGY}

The study was conducted in the settlements of Gomoa Ngyiresi, Gomoa Odina,

\footnotetext{
'Despite its undeniable benefits, there are several constraints to cassava production. Pests and diseases frequently attack the crop resulting in yield losses that may be as high as $50 \%$. Cassava requires good quality stem and the multiplication rate of the stems is rather low. Furthemore, cassava requires considerable labour to harvest and the crop must be processed inmediately after harvest because it is highly perishable. Sone varieties of cassava are also higlily toxic with high levels of cyanogenic glucosides (IITA, 2004).
} 
Dominase, and Ojobi in the Gomoa District as well as in the settlements of Bawjiase, Ayensuako, Jei Krodua and Bonsueku in the Awutu-Effutu-Senya District. Both the Gomoa and the Awutu-Effutu-Senya Districts are located in Ghana's Central Region. The study was carried out, primarily, among smallholder farming households in the two districts. Additional extensive surveys were carried out among cassava farmers in and around Bawjiase, where the Ayensu Starch Company Limited (ASCO) set up by the government to process cassava into starch for export is located. Besides the individual smallholder cassava farmers, a considerable part of the research effort was spent interviewing the staff and management of the ASCO.

In all, data and information were obtained from 80 farmers from the two districts during the six months research period, between January and June 2004. The sample population included smallholder farmers from communities in the two districts, the management and staff of the ASCO resident at Bawjiase and its environs, and the executives and members of the Ayensu Cassava Farmers Association (ACFA) in the Gomoa and the Awutu-Effutu-Senya Districts. The communities were selected using the purposive method while the individual farmers were selected from a list provided by members of the ACFA within the community.

Participant observation, during which the author stayed with and participated in the day-to-day activities of the selected farmers was the fundamental method employed in the survey. Interviews and questionnaires were utilised during different stages of data collection. Farmers at Bawjiase and Ayensuako, the executives of ACFA and the management of ASCO were interviewed over several days during the period of the research work. In Gomoa Ngyiresi, and Gomoa Odina, questionnaires were administered to the executives of ACFA. Similarly, questionnaires were also administered to the staff and management of ASCO. ${ }^{2}$

The Gomoa District is located in the southeastern part of Ghana's Central Region. $74 \%$ of the district's 194,792 inhabitants live in the rural areas. Agriculture (including crop farming, animal rearing and fishing) constitutes the main occupation in the district with an estimated $50 \%$ of the population working in this sector. The rest are engaged in trading, small scale processing and provision of services. The major crops grown are cassava, maize, oil palm, coconut and vegetables. The main livestock reared are cattle, goats, sheep, pigs and poultry (Gomoa District Assembly, 2001).

The neighbouring Awutu-Effutu-Senya District, on the other hand, has a total population of 162,972 inhabitants with about $68 \%$ of the population living in the urban areas. About $48 \%$ of the residents are engaged in food-crop production. Another $6 \%$ herd livestock as their major source of living. Trading (28\%) and services (18\%) are

\footnotetext{
2 would like to express ny sincere gratitude to Cyril King who assisted with the administration of questionnaires at the Ayensu Starcli Company as part of his Long Essay submitted to the Department of Sociology, University of Ghana, Legon (sce King. 2(0)4).
} 
other economic activities of the inhabitants. Just as in the neighbouring Gomoa District, most of the smallholder farmers are involved in the cultivation of oil palm, coconut, cassava and vegetables (Awutu-Effutu-Senya District, 2001).

Cassava production constitutes the major economic activity in both the AwutuEffutu-Senya and the Gomoa Districts. The Awutu-Effutu-Senya District has a total of 27,520 hectares under cassava production and produced 366,800 Metric tonnes of the crop in 2003. The Gomoa District, on the other hand, produced only about 56,062 Metric tonnes of cassava in that year (MOFA 2004).

The bulk of the cassava produced in both districts is from smallholder farmers who cultivate less than one hectare of land usually on the household's plot of land. Wealthier farmers who cultivate larger fields of up to 3 hectares, would in addition to household labour, hire labour to complete many of the agricultural tasks including land preparation, planting, weeding and harvesting. Cassava yields on smallholder household farms in the two districts are reported to have increased from 5-6 tonnes per hectare to nearly 20 tonnes following the introduction of improved varieties and the adoption of improved farming methods (RTIP undated) ${ }^{3}$

\section{THEORETICAL ISSUES}

\section{Transforming Smallholder Farming in Ghana}

In Ghana, just as in most parts of Africa, the vast majority of the nation's food crops are produced by farmers who cultivate small acreage of land. They use mainly household labor and produce primarily to meet the household's food requirements. Any excess in food production beyond what is needed to meet the economic, social and religious needs of the household is often sold on the market. Development sociologists and agricultural economists have generally labeled such smallholder producers as "subsistence producers". Although there is no doubt about the type of production being referred to, there are some disciplinary differences in what are considered the main features of subsistence production. Agricultural economists tend to focus on the share of production devoted to the household's own consumption. Thus, farmers who predominantly produce for their own consumption are labeled subsistence producers while those who produce mainly for sale on the market are considered commercial farmers. Since all farmers are engaged in some form of market exchange, the part of the produce that is marketed is frequently used to differentiate between subsistence and commercial farmers. Often an arbitrary measure of $50 \%$ of the allocation of household produce is used to differentiate between subsistence and commercial producers (Brüntrup \& Heidhues, 2002; Wharton, 1970). In addition to this, subsistence

\footnotetext{
'Four improved varieties were introduced to Ghana by the Intentational Institute of Tropical Agriculture (IITA) between 1984 and 1998. The four varieties have been christened A fisiafi, Gblemo duade. Abasafitaa and Tek bankye. They are. in comparison with the local varieties. not only high-yielding but also disease/pest tolerant. early maturing and have a high dry matter content (RTIP, 1999; RTIP. undated).
} 
production often characterizes the use of household labor, simple and inexpensive farming equipments (such as the hoe, cutlass, and stick), the cultivation of several different staple foods on a small plot of land (usually less than three hectares), and the use of few farming inputs (improved seedlings, fertilizer and pesticides) for farming (Kwarteng \& Fowler, 1994: 297-8).

Sociologists and anthropologists, on the other hand, have generally focused on the social relations that characterize production by smallholder farmers. They have emphasized the fact that factors of production such as land and labour are frequently communally-owned and managed. An extensive network of social relations characterizes production, distribution and consumption activities of smallholder farmers. Besides, production activities are embedded in a context of elaborate social relations and religious ceremonies. Economic activities among Africa's smallholder farmers have therefore been summarily described as being a "moral economy" or an "economy of affection" (Hyden, 1983; Scott, 1976).

Recent studies have, however, drawn attention to the fact that Africa's rural smallholder farmers are increasingly being integrated into the national and international capitalist economy. They therefore advocate the need to move beyond the subsistence-commercial farmer dichotomy to view both producers as integral to the capitalist economy, although varying in degrees. Whilst some commercial farmers may be highly integrated into the capitalist economy in terms of their produce and their production methods, smallholder farmers are inseparably linked directly or indirectly through a chain of markets to the national economy. Besides, there has been a massive expansion of the market into spheres that were hitherto dominated by subsistence forms of production. The two forms of production are therefore inseparably linked to each other, influencing one another much more than it was previously presumed (Evers, 1984, 1997; Lachenmann \& Dannecker, 2001).

Irrespective of its characterization, smallholder subsistence farming has become an increasingly pejorative term. It has become synonymous with traditionalism, unwillingness to change, inefficiency and a generally backward form of land use and production. It is generally believed that as part of the modemization process, there is the need to transform subsistence agriculture into commercial agriculture by encouraging production for the market, through the use of modern farming methods such as agricultural machinery, high-yielding varieties, fertilisers and pesticides. Colonial and post-colonial governments in Africa have therefore tried to transform smallholder subsistence farmers producing mainly for household consumption into commercial farmers producing for national and international markets. During the colonial period, smallholder food-crop producers were encouraged to shift emphasis from food-crops to the production of cash crops such as cocoa, coffee, rubber, groundnuts etc. that were needed in the metropoles of the various European colonial powers. This trend has continued into the post-colonial era. Successive Ghanaian governments have also encouraged nural farmers to produce cash crops as a means of generating income and foreign exchange required to pursue their socio-economic infrastructural programmes 
(Eicher \& Baker, 1982; Hansen, 1989).

Since independence in 1957, several Ghanaian governments have implemented agricultural policies that sought to transform the nature and organization of smallholder farming in the country. The various government policies were largely informed by the belief that smallholder farming was inefficient and a hindrance to national progress and therefore had to give way to large-scale farming. This transformation from smallholder subsistence farming to large-scale farming was generally considered to be in line with the modernisation policy that interpreted social progress as a movement from traditional to modern agriculture (Hansen, 1989).

During the decade preceding independence (1951-57), the Nkrumah government's policy was to transform Ghanaian agriculture by encouraging the numerous smallholder farmers to go into the cultivation of cash crops, especially cocoa. The policy aimed at transforming smallholder farming by encouraging them to set up or rehabilitate plantations for cash crops such as cocoa, banana and oil palm (Gyimah-Boadi, 1989). Upon the attainment of independence in 1957, this emphasis on smallholder sector changed and the government policy shifted to the setting up of statesponsored, large-scale mechanized agriculture through the establishment of cooperatives and a policy of collectivisation. The large numbers of subsistence farmers were also organized into the United Ghana Farmers' Co-operative Council and the Young Farmers League. These organisations were responsible for organising smallholder farmers into cooperatives and providing them with technical and financial assistance (Gyimah-Boadi, 1989:224). The Nkrumah regime succeeded in encouraging smallholder farmers to expand the cultivation of cash crops, especially cocoa, and to rehabilitate their cocoa farms. Ghana's cocoa output reached an all-time high in 1965. Otherwise, its agricultural policy of transforming smallholder agriculture through a policy of collectivisation and state-sponsored farms was a dismal failure (Dadson, 1973; Miracle \& Seidman, 1968).

The National Liberation Council (NLC) that succeeded the Nkrumah government completely ignored smallholder farmers. The NLC government rather promoted what it referred to as the "modern farmer". The government sought to attract the educated and professional class to go into large-scale commercial farming. Besides the provision of credit facilities to the so-called modern farmer, additional incentives such as tax concessions were also given to professionals to go into rice and maize cultivation. According to Gyimah-Boadi (1989: 228), the NLC's agricultural policies were "largely ineffective and negative". The succeeding Progress Party (PP) government (1969-70) did not attempt to directly influence smallholder farming. Instead, it hoped to increase food production through an improvement in the general conditions of rural livelihood. Its policy of rural development focussed on the construction of feeder roads, the provision of health posts, electricity and water and the improvement in housing in the rural areas of the country. The PP government also continued with the policies of its predecessor that promoted large-scale farming by private capitalists (Gyimah-Boadi, 1989; Hansen, 1989; Krauss, 1986). 
The NRC/SMC government's (1972-77) agricultural policies were aimed at increasing food production for the domestic market as well as the production of raw materials for Ghana's fledging industries. ${ }^{4}$ This was to be achieved through the various Regional Development Corporations (RDC) that were set up throughout the country to liaise with the various state agencies in the agricultural sector and to serve as centres for the provision of technical support and the infusion of modern agricultural technology to what was considered to be the largely backward peasant farmers. The policy was to support large-scale farmers with agricultural credit and inputs so that they would serve as change-agents for the transformation of smallholder farmers in the regions. The RDCs supported public and civil servants, serving and retired military officers, as well as professionals to go into large-scale commercial cultivation of rice, tomatoes, cowpea etc. It was expected that they would ultimately transfer their advanced farming technology to rural farmers in their areas of operation (Tonah, 1993; Shepherd, 1979). ${ }^{5}$

The PNDC/NDC government's (1981-2000) agricultural policies did not directly target the smallholder farmer. It was more concerned with the rehabilitation of the cocoa sector and the implementation of a series of measures aimed at "getting prices right" (cf Eicher \& Baker, 1982). The policy aimed at eliminating the huge bureaucracy that was associated with food and cash crop production and to stimulate agricultural production by realigning relative prices in favour of producers. Subsidies on agricultural inputs such as fertilisers, pesticides, and farming equipment were progressively reduced (Nyanteng \& Seini, 2000). Hansen (1989:216) argues that the PNDC government's policy of Block Farming was very similar to the NRC government's Special Agricultural Scheme. As part of the Block Faming system, farmers from neighbouring villages were brought together to undertake farming activities collectively thus enabling them benefit from the infrastructure of large-scale farming and have access to credit, mechanised services, input delivery services, storage and marketing facilities.

Attempts by various Ghanaian governments to transform subsistence farmers into large-scale commercial farmers have not been particularly successful. The bulk of the country's food-crops and agricultural produce is still produced by rural smallholder farmers. It is against this background that the paper now examines the Presidential Special Initiative on cassava and current efforts to transform smallholder farmer production.

\footnotetext{
"These agricultural progranumes wcre coordinated under the Operation Feed Yourself (OFY) and the Operation Feed Your Industries $(O F Y I)$ programmes of the govenument. The OFY concentrated on the production of cereals (nrainly maize and rice) while the OFYI supported the production of agricultural raw materials such as cotton, kenaf, sugar cane etc. (Nyanteng \& Seim. 2000).
}

For a detailed analysis of one of the most prominent Regional Development Corporations (the URADEP) see Konnings (1980) and Clombas (1981). 


\section{THE PRESIDENTIAL INITIATIVE (PSI) ON CASSAVA}

In January 2001, the ruling New Patriotic Government (NPP) launched the Presidential Special Initiative (PSI) policy that was expected to ginger public-private sector partnership by creating a practical enabling environment for identified competitively advantageous industries with potential for fast growth and demand from export markets to take off with well-designed intervention mechanisms. The PSIs were intended to stimulate enterprise, productivity and jobs, both in agriculture and in processing. Currently, PSIs have been launched on cassava, garments and textiles, salt, and oil palm. These ambitious projects were expected to generate an overall export revenue earnings of about US $\$ 4.4$ billion and create some 100,000 jobs within the next four years (Martey, 2004; Public Agenda of October 27, 2003; Sam, 2002).

The PSI on cassava was the very first to be established as part of the government's policy of transforming cassava production from its subsistence nature into a commercially viable agribusiness that can generate substantial revenue locally and through exports, while at the same time addressing rural poverty by bringing rural communities into mainstream economic activity (King, 2004). Although the government is the main sponsor of the PSI, the project is planned to be based on a farmer-ownership scheme called the Corporate Village Enterprise (COVE) model. The COVE model seeks to bring rural communities into mainstream economic activity by establishing large-scale export-oriented enterprises, which will be owned by farmers themselves but managed by professionals with industrial experience who will be engaged on performance contracts. In consonance with this policy, farmers in the two districts were encouraged to form cooperatives. Members of the cooperatives were expected to grow the crop on their individually-owned farms and then be assisted by the government to collectively own a starch processing plant established by the government to process cassava into starch (Sam, 2002).

The specific objectives of the PSI on cassava as envisaged by the government were, among others to:

- transform the cassava industry into a major growth pole by the end of 2006

- establish 10 cassava starch processing plants by the end of 2006

- generate annual export revenues of 100 million US dollars by the end of 2006

- ensure that $50 \%$ of farmers participating in the project are women.

The intended social benefits of the project were said to be numerous and included the following:

To generate employment amongst the rural population. The average family size of the rural household was estimated to be six. 
- To promote the growth of allied business through irrigation agriculture.

To contribute to the development of social infrastructure in the communities concerned. It is expected to lead to better health care and improved educational facilities.

- To provide equal opportunities to women through ensuring that $50 \%$ of farmers participating in the project are women.

- To promote the development of infrastructural facilities in the area including roads, electricity, pipe-borne water etc.

- Increase the productivity of the rural smallholder farmer from itscurrent levels of 5 tonnes per acre.

\section{The Ayensu Starch Company}

The Ayensu Starch Company (ASCO), a public-private partnership, was established at Bawjiase in 2001 and officially commissioned in June 2004. It was the very first of the 10 intended industrial plants meant to process cassava into industrial starch. The company's shareholders include private businessmen and women who provided the initial investment that was required to establish the company. The company, however, received considerable financial and technical assistance from the government and other public agencies such as the Ministry of Trade, the Ministry of Food and Agriculture and the respective District Assemblies.

\section{The company has the mandate to:}

- undertake and assist in the undertaking of the cultivation of agricultural produce.

- purchase, take, lease or otherwise acquire land or right to land in Ghana or elsewhere for agricultural and agricultural processing purposes.

- hold, store, transport, process, and value prepared for market and export agricultural produce.

- syndicate and secure financing for agricultural production, processing and research.

- explore and secure local and foreign markets for agricultural purchases either in its raw or processed state and

undertake research into agricultural production and processing technology and disseminate such results, information and findings.

The Government of Ghana and its development partners ${ }^{6}$ were expected to complement the efforts of the private entrepreneurs by supporting the project with infrastructural facilities namely the :

\footnotetext{
"The main devclopment partmers in the project include the UNDP Enterprise Africa. DANIDA. the International Financial Consortium ( $1 \mathrm{FC}$ ). and several banking institutions including the Oiko Credit (Netherlands), the National Investment Bank (N'IB) and the Glaana Commercial Bank (GCB).
} 
- construction/upgrading of access roads to the farms and the factory site.

- provision of communication facilities within the operational zone.

provision of adequate power to the processing plant and the surrounding communities and

- provision of potable water to the factory as well as the surrounding communities.

As part of its operations, the ASCO acquired 35 hectares of land on which the company has planted a high-yielding variety of cassava. The project initially recruited 235 persons as farm workers as well as a number of persons as tractor operators and technicians. During the period of the research, 10 out of the 35 hectares planted had already been harvested but the remaining fields were overgrown with weeds. In May 2004 , there were only six farm workers out of the 235 persons recruited at the beginning of the project and they were working with simple tools such as cutlasses and hoes. The workers claimed that the cassava harvester available was not suitable for the type of cassava grown, the soil type and the nature of the farm. The farmers also indicated that the harvester made their work more tedious and wasted their time and therefore preferred to use their bare hands and chisel to uproot the cassava crop. The farmers were paid 30,000 Cedis for every tonne of cassava harvested. Cassava harvested from the ASCO farms are transported to the factory site located about two kilometres from the town centre where the produce is weighed and processed.

\section{Mobilizing Rural Farmers: The Ayensu Cassava Farmers Association (ACFA)}

The Corporate Village Enterprise (COVE) model upon which the Presidential Special Initiative on cassava project is based, is intended to be farmer-driven, owned and managed. The initial process was therefore devoted to mobilizing rural farmers into associations with the intention of eventually turning these associations into cooperatives. With the assistance of field staff trained by the ASCO, farmers' associations (called the Ayensu Cassava Farmers' Association, ACFA) were set up throughout the catchment area of the project within the Gomoa and the Awutu-Effutu-Senya Districts. The field-staff with the assistance of the Ministry of Food and Agriculture moved from one settlement to the other informing the farmers about the impending project on cassava and the roles expected of farmers and the government in the project. They also convinced rural farmers about the benefits of cassava production. They assured them of a ready market for their produce at the starch factory in Bawjiase. Farmers within a locality were therefore to be mobilized into a local branch of the ACFA.

By 2004, several branches of the ACFA had been formed in the Central, Eastern and the Greater Accra Regions of Ghana. The total membership of farmers in the ACFA

\footnotetext{
The loaded tractor is weighed by driving over a weighing mechansm. After the tractor has discharged its luggage. the vehicle is again weighed and the difference between the two weights is given as the amount of cassava harvested. The sane procedure is applied to fammers working outside the ASCO concessions who sell their harvested cassava produce to the factory.
} 
was estimated at 8,000 . The association also employed 12 Extension Officers to support the various local branches of ACFA and to support them in their attempt to produce fast-growing, high-yielding and quality cassava.

The stated objectives of the ACFA include the following:

To promote the cultivation of cassava to ensure high output of the Ayensu Cassava Starch factory and thereby ensure the success of the first corporate village enterprise established under the PSI on cassava.

To monitor cassava and starch price trends, negotiate for fair prices and arrange for the marketing of members' produce.

To bring all participating out-grower cassava farmers in the Ayensu Starch Company under one umbrella to facilitate effective communication, production, planning, and dissemination of new technologies/farming techniques.

To educate and sensitise its members to produce high quality cassava suitable for starch production.

To arrange for the supply of cassava planting materials and other agricultural inputs such as chemicals, machetes, and field boots at affordable prices to its members.

To provide opportunities to access credit/loans, financial resources, and establish rural savings and credit scheme for its members

To promote, foster, protect and maintain the interest of its members through advocacy.

To establish additional income-generating activities in the community as a whole and create employment for the youth.

\section{The Impact of the PSI on Smallholder Farmers}

It is probably still too early to provide a final assessment of the activities of the Ayensu Starch Company (ASCO) and the impact of the PSI on smallholder farmers in the two districts. However, barely two years after the establishment of the ASCO, the operations of the company have already started experiencing problems that are crippling its production efforts and affecting its ability to perform as envisaged. The supply of raw materials (cassava) to the factory is poorly organized and can no longer be guaranteed. Many farmers who were initially delivering their produce to the factory had decided to sell their produce on the local markets. This is because of the higher price of cassava on the local markets. This is happening at a time that the factory is producing far below its current installed capacity of about 20,000 tonnes of cassava per annum.

Furthermore, the ASCO has not been able to manage successfully the 35 hectares cassava field that it acquired. Large parts of the field remain weedy and not harvested for long periods, thus, increasing the likelihood that the cassava produced spoiling. 
The company already has considerable problems maintaining its field workers. The poor remuneration, delays in the payment of staff, lack of rapport between the management and the workers and the generally low morale among the workers have already affected the staff strength of the company. The number of field workers had reduced from 235 at the beginning of the project to about six persons in 2004. Similarly, the company's agricultural machinery such as tractors and harvesters are either inadequate or unsuitable for the kind of work they are supposed to accomplish. The result is that the field workers are compelled to use their bare hands and without any protective wear to execute their tasks (King, 2004).

Probably the most critical factor that is likely to affect the future fortunes of the project is the low morale and motivation among the fieldworkers. Fieldworkers on the ASCO farm complain about being poorly treated by the management of the factory: salaries are low and paid irregularly; there is a lot of drudgery associated with working with the company due to the absence of basic working tools and equipment; machinery available are unsuitable for the task to be accomplished; and the relationship between fieldstaff and management appears strained. Fieldworkers also bemoan the absence of basic infrastructural facilities such as transportation to the farms and drinking water. A survey of 20 farmers in each of the settlements of Bawjiase, Gomoa and among ACFA members in Ayensuako indicated their most pressing problems as the difficulties associated with transporting their produce to the factory, the poor prices paid by the ASCO for their produce, and the generally poor farmerASCO relations. Many farmers also complained about the inadequate government support for their communities (see Table 1).

\section{Table 1: Farmers Complaints in Study Area}

\begin{tabular}{|l|l|l|l|}
\hline Farmers' Complaints & $\begin{array}{l}\text { Frequency of } \\
\text { re s p o n s e } \\
\text { (Bawjiase) N=20 }\end{array}$ & $\begin{array}{l}\text { Frequency } \\
\text { response } \\
\text { (Gomoa) N=20 }\end{array}$ & $\begin{array}{l}\text { Frequency of response } \\
\text { (Ayensuako) N=20 }\end{array}$ \\
\hline $\begin{array}{l}\text { Poor farmer-ASCO } \\
\text { Relations }\end{array}$ & $18(90 \%)^{8}$ & $20(100 \%)$ & $20(100 \%)$ \\
\hline $\begin{array}{l}\text { Lack of donor } \\
\text { support to farmers }\end{array}$ & $10(50 \%)$ & $14(70 \%)$ & $17(85 \%)$ \\
\hline $\begin{array}{l}\text { Poor prices for produce } \\
\text { Difficulties transporting }\end{array}$ & $16(80 \%)$ & $20(100 \%)$ & $18(90 \%)$ \\
\hline Produce to ASCO factory & $20(100 \%)$ & $20(100 \%)$ & $20(100 \%)$ \\
\hline
\end{tabular}

\footnotetext{
"This simply means that 18 out of 20 farmers (that is, $90 \%$, interviewed in Bawjiase mentioned "poor farmer-ASCO relations" as a problem. 10 out of the 20 farmers (50\%) in Bawjiase mentioned "lack of donor support to farmers" etc. etc. There were multiple complaints from each of the 20 farmers.
} 
Ghana Journal of Development Studies Volume 3, Number I. May 2006

\begin{tabular}{|l|l|l|l|}
\hline $\begin{array}{l}\text { Pollution of factory } \\
\text { lenvironment }\end{array}$ & $10(50 \%)$ & $0(0 \%)$ & $0(0 \%)$ \\
\hline Delays in paying farmers & $20(100 \%)$ & $20(100 \%)$ & $16(80 \%)$ \\
\hline $\begin{array}{l}\text { Inadequate government } \\
\text { support to farmers }\end{array}$ & $14(70 \%)$ & $12(60 \%)$ & $8(40 \%)$ \\
\hline $\begin{array}{l}\text { Inadequate government } \\
\text { support to community }\end{array}$ & $18(90 \%)$ & $18(90 \%)$ & $16(80 \%)$ \\
\hline
\end{tabular}

Source: Author's survey, May 2004.

The low morale has apparently contributed to the increasing malfeasance among the workers. The field workers of ASCO tend not to use the company's tools, equipment and machinery with the necessary care and are not particularly inclined to protect and ensure the safety of the company's equipment. Instead, they have developed a rather apathetic attitude to the company's property. All attempts are made to obtain additional income from the company sometimes through illegal means: cassava brought to the factory may not be in good condition; besides, cassava sold to the factory may be mixed with foreign materials such as cassava stems, just to increase the weight of their produce and oblain more money.

The farmers' organisations set up under the ACFA in the various localities are no longer functioning efficiently. The enthusiasm that characterised these farmers' associations at the initial stages of the project no longer exist. Members of the local farmers' association no longer attend meetings while some have stopped cultivating the high-yielding cassava variety meant for the ASCO factory. Instead, they have taken to the cultivation of local varieties and other crops that can be sold on the local market. ${ }^{9}$ This is because of what they claimed to be "the bad treatment given to them by the company".

Their harvested produce is left at the farm gates with no means of transport to take them to the ASCO factory. Some vehicle owners also refuse to transport their produce because of what they claim are the poor prices paid by the factory. Farmers are also unable to pay their farm labourers because of the low prices paid for their produce. A landlord at Bawjiase whose compound served for three years as the meeting point of the local branch of ACFA had this to say about the activities of the association:

These days when they (ACFA) call for meetings people do not turn up, and even the large articulator trucks and haulers that used to bring cassava from the hinter-

\footnotetext{
"Some of the improved varietics of cassava such as the Afisiafi and the Gblemo duade art unsuitable for the preparation of the commonest local dishes including fuf $u$ and Ampesi. They are. however, suitable for the preparation of other dishes such as Gari, Agbelima and Kokonte that are not widely consumed in the area. Fanmers in Bawjiase who cultivated these varieties were thercfore conpelled to buy other cassava varieties from the market to meet their household food requireneints.
} 
lands have all deserted the company. Most of the farmers complain about getting irucks to convey their cassava from the farms to the factory. The farmers are not being paid well so definitely they cannot also pay the drivers, their labourers and the truck owners well. This is why people are not patronising the association these days and it looks like it is dying.

Generally, the ASCO management acknowledges the existence of these problems and the growing disillusionment of farmers with the project. They, however, consider these as part of the "teething problems of the company that would soon be a thing of the past when the cooperative ownership concept of the project is fully implemented" (Daily Graphic, October 21, 2003). The ASCO management also attribute the pricing problems to "a communication gap" between farmers and management. Management still continued to believe in the viability of the project and was hopeful that with improved agronomic practices, higher yields per hectare would soon be recorded to enable the farmers earn more income and reduce poverty.

\section{SUMMARY, DISCUSSION AND CONCLUSION}

This paper has analysed a special initiative by the ruling NPP government to increase the incomes of smallholder farmers in the Central Region of Ghana and improve upon their livelihood through increased cassava production and the processing of their produce into starch for exports. Smallholder farmers in the Gomoa and the Effutu-Awutu-Senya Districts were organised into cooperative farmers and then provided with technical assistance and credit facilities to enable them expand their acreage of cassava production and the productivity of their farming venture. The starch factory was also provided with infrastructural support including the construction of a road network to the factory, and the provision of water and electricity to the factory.

The paper, however, noted that in spite of the goodwill and support of the government for both the expansion in cassava production as well as the starch factory, the PSI for Cassava is encountering numerous teething problems barely four years after it commenced operations. The initial enthusiasm that characterized the commencement of the project is slowly giving way to disillusionment and despondency on the part of many smallholder farmers. Many of the newly created cassava farmer associations in the area that were hitherto active and dynamic are now dormant and ineffective. Farmers are no longer attending meetings regularly and the entire cooperative concept has not yet developed as envisaged by the government. The Ayensu Starch Company (ASCO) has also been bedevilled by a number of bottlenecks. It is having problems harvesting its large cassava farm due to the non-availability of farm hands and equipment. The company has been forced to retrench a substantial part of the initial field staff employed to manage the cassava farm. Besides, the company has been unable to hire labour from the neighbouring communities as most farm hands complain about the low wages paid by the company. The ASCO is also unable to cart cassava from the hinterland to the factory premises due to the non-availability of 
trucks. Farmers, on the other hand, are unable to hire vehicles to transport their produce to the factory premises due to the high cost of transportation.

Besides the problem of transportation, there is also the problem of pricing of cassava. Smallholder farmers are unhappy with the price paid by the ASCO for their produce and there is yet no compromise solution on this issue. Farmers who were hitherto supplying their cassava to the factory have now resorted to selling their produce on the local market. Others have moved from the cultivation of cassava meant primarily for the production of starch into other varieties that can be used in the preparation of local meals. The effect of all of this is that the Ayensu Starch Factory is currently producing well below its installed capacity.

Despite the difficulties that the ASCO project in Bawjiase is currently facing, it is still too early to judge the success or otherwise of the PSI on cassava. However, there is no doubt that some of the objectives including transforming the cassava industry into a major growth pole, establishing 10 cassava starch processing plants and generating an annual export revenue of US $\$ 100$ million by 2006 were very ambitious and unlikely to be attained within the given time frame. Besides, the project does not appear to have taken into consideration the experiences of local private companies in the production and marketing of cassava starch and other cassava products. A recent study by the International Fund for Agricultural Development (IFAD) indicates that cassava starch/flour produced in the country is of poor quality and uncompetitive because "it is prepared from unpeeled cassava roots that are sun dried, coarsely milled, screened, and blended with other adhesive components". Similarly, local plywood factories that have tried using cassava flour/starch as glue complain that the product "was not milled properly, insufficiently dried and contained many insoluble impurities that caused blistering in the plywood sheets" (IFAD/FAO, 2004: 53).

The study indicated that the factory is facing stiff competition from private traders in obtaining raw materials (cassava) required for its production. There is a thriving market for foodstuffs in the nearby Kasoa and Accra markets. Farmers therefore prefer to sell to private traders who are considered to be less bureaucratic and would make onthe-spot payments for any cassava purchased. The ASCO is unable to compete with private traders by offering equally lucrative prices for cassava. The factory would therefore have to depend on cassava coming from farmers living in the rural hinterland with poor access to the local market.

The study has also shown that the revival of the numerous ACFA is indispensable for a profitable and sustainable operation of the factory. A processing factory that is dependent on a large number of smallholder farmers for its supply of raw materials has to promote close collaboration and trust with these farmers. For a fruitful relationship between a processing factory and the numerous smallholder out-growers, there is the need to organise the out-growers into active cooperatives, provide extension support, credit and training to the farmers and provide a field-based system that can guarantee the necessary quality control among rural producers. This is a better way of reducing 
constraints that face rural smallholder farmers, providing them with a regular source of income, reducing poverty and ensuring their gradual and risk-free integration into mainstream economic activity. The relationship between privately-owned processing firms and smallholder farmers' cooperatives in the pineapple industry in Southern Ghana is an example worthy of emulation by the ASCO management, government officials and technocrats in charge of the PSI on Cassava (cf Yeboah 2003).

Finally, the analysis of the PSI on cassava was within the context of past attempts by various Ghanaian governments to improve the general livelihood of rural farmers. This is to be done by rapidly transforming the nature of agricultural production from its smallholder, subsistence level and its traditional orientation to that of a modern commercial business venture that can propel the nation towards self-sufficiency in agricultural production and food security. It noted that past governments did not put their money where their mouths were. Their support for agricultural production, and particularly the pledge to improve rural livelihood was mainly political rhetoric and goodwill. The rhetoric about transforming rural livelihood and the lives of smallholder farmers continued even when public expenditure on agriculture continued to decline progressively (Hansen, 1989). Instead of encouraging smallholder farmers to take up high-cost mechanized farming characteristic of agribusinesses, this study supports the view that what is required is the introduction of new, simple, and affordable technologies that can increase production, reduce the drudgery of work among subsistence farmers as well as bring down the cost of production, harvesting, processing and marketing of cassava. As income levels of smallholder farmers gradually rise, they would embrace useful innovations that are affordable, labor-saving and productivity-enhancing.

\section{REFERENCES}

Awutu-Effutu-Senya District Assembly (2001). Sources of household income. Winneba: AES District, Planning and Data Unit.

Brüntrup, M. \& F. Heidhues (2002). Subsistence agriculture in development: Its role in processes of structural change. Discussion Paper No. 1/2002, Center for Tropical Agriculture, Institute of Agricultural Economics and Social Sciences in the Tropics and Subtropics. Hohenheim: University of Hohenheim.

Chambas, M. (1981). The politics of agricultural and rural development in the Upper Region of Ghana: Implications of technocratic ideology and nonparticipatory development. Unpublished PhD Thesis. USA: Cornell University.

Dadson, E. (1973). Farm size and the modernization of agriculture in Ghana. In I. M. Ofori (ed). Factors of agricultural growth in West Africa (193-202). Legon: ISSER.

Eicher, C. \& D. Baker (1982). Research on agricultural development in Sub-Saharan Africa. Michigan: MSU International Development Paper No. 1. Michigan. 
Evers. H.-D. (1984). Subsistence reproduction: A framework for analysis. In J. Smith, I, Wallerstein H.-D. Evers (eds). Households and the World Economy (2336). Beverley Hills: Sage.

Evers, H.-D. (1997). Marktexpansion und Globalisierung. In M. Schulz (ed). Entwicklung. Die Perspektive der Entwicklungssoziologie (213-222). Opladen: Westdeutscher Verlag.

Food and Agricultural Organisation (FAO) (2004). Championing the cause of cassava. In www, fao.org/news/200/000405-e.htm, accessed 3rd November, 2004.

Gomoa District Assembly (2001). Sources of household income. Apam: Data Unit.

Gyimah-Boadi, E. (1989). Policies and politics of export agriculture. In E. Hansen \& K. A. Ninsin (eds). The state development and politics in Ghana (222-241). London: Codesria.

Hansen, E. (1989). The state and food agriculture. In E. Hansen \& K. A. Ninsin (eds). The state development and politics in Ghana (184-221). London: Codesria.

Hyden, G. (1983). No shortcuts to progress. African development management in perspective. Berkeley: University of California Press.

International Fund for Agricultural Development (IFAD)/Food and Agricultural Organisation (FAO) (2004). Global cassava market study. Busıness opportunities for the use of cassava. Rome: FAO \& IFAD.

International Institute of Tropical Agriculture (IITA) (2004). Cassava.

In www.iita.org/infor/rcmdthers.htm, accessed 3rd November, 2004.

King, C. (2004). The presidential special initiative (PSI) on cassava and its unintended consequences. B.A.

Long Essay, Department of Sociology. Legon: University of Ghana.

Könings, P. (1986). The state and rural class formation in Ghana: A comparative analysis. London: KPI Limited.

Krauss, J. (1986). The political economy of agrarian regression in Ghana. In Stephen Cummins et al Africa's agrarian crisis: The roots of famine. Boulder, Colorado: Lynne Reiner.

Kwarteng, J. A. and M. J. Fowler (1994). West african agriculture. London: Macmillan. 
Lachenmann, G. and P. Dannecker (2001). Die geschlechtsspezifische Einbettung der Ökōnomie. Munster:Lit Verlag.

Martey, S. (2004). Salt: Ghana's white gold. A special study on the presidential special initiative (PSI) on salt's prospects. B. A. Long Essay, Department of Sociology. Legon: University of Ghana.

Miracle, M and A. Seidman (1968). Agricultural cooperatives and quasi cooperatives in Ghana 1951-65. Madison: Land Tenure Centre, University of Wisconsin.

Ministry of Food and Agriculture (MOFA)(2004). Production of major crops in the Central Region - 2003. Accra: Statistics, Research and Information Directorate, MOFA.

Nyanteng, V. K. and A. Wayo Seini (2000). Agricultural policy and the impact on growth and productivity 1970-95. In E. Aryeetey, J. Harrigan and M. Nissanke (eds). Economic reforms in Ghana. The miracle and the mirage. Oxford: James Currey.

Nweke, F. (2004). New challenges in the cassava transformation in Nigeria and Ghana. Discussion paper No. 118. Washington: Environment and Production Technology Division, IFPRI.

Root and Tuber Improvement Programme (RTIP) (undated). Steps to good cassava production. Kumasi: MOFA.

Root and Tuber Improvement Programme (RTIP) (1999). Varietal characteristics of four improved cassava varieties. RTIP Factsheet No. 1. Kumasi: MOFA.

Sam, K. (2002). President launches export initiative. File://Al/President launches export initiative.htm, accessed $31^{\text {st }}$ October, 2004.

Scott, J. (1976). The moral economy of the peasants. New Haven: Yale University Press.

Shepherd, A. (1979). The development of capitalist rice farming in Northern Ghana. Unpublished $\mathrm{PhD}$ Thesis. Cambridge: University of Cambridge.

Tonah, S. (1993). The development of agropastoral households in Northern Ghana. Saarbrucken:Breitenbach Publishers.

Volz, A. (1990). Traditionelle Anbaustrategien Westafrikanischer Bauernkulturen. Münster: Lit Verlag. 
Ghana Journal of Development Studies Volume 3, Number 1, May 2006

Wharton, C. R. (1970). Subsistence agriculture: Concepts and scope. In Warton (ed). Subsistence agriculture and economic Development (12-20). London.

Yeboah, G. (2003). The farmapine model: A cooperative marketing strategy and market based development approach. In www.saga.cornell.edu/images/cau-yeboah.pdf, accessed $15^{\text {th }}$ November, 2004. 